\title{
保水性コンクリートブロック舗装の 路面温度上昇抑制効果に関する研究
}

\author{
唐沢明彦 ${ }^{* 1} \cdot$ 藤田 仁 $^{* 2} \cdot$ 江角典広 ${ }^{* 3} ・$ 高森哲也*4
}

\begin{abstract}
概 要 2005 年 7 月, 社団法人 インターロッキングブロック舗装技術協会により保水性コンクリートブロックの品 質性能規格およびその試験方法が制定された。この概要について紹介する。著者らは，この品質性能規格を満足する 15 種類の保水性コンクリートブロックを実環境下に施工し，夏季の路面温度上昇抑制効果に関する実証的な実験結果を得た。 そして, 実験結果の解析から「保水性コンクリートブロックの品質性能」「コンクリートブロックの表面色」「クッション 砂抢よび目地砂の存在」「舗装への給水システム」が路面温度に及ぼす影響を検証および確認できたことから，これらを 取りまとめて報告する。

キーワード：保水性舗装，コンクリートブロック，品質性能，路面温度
\end{abstract}

\section{1.はじめに}

近年，我が国ではヒートアイランド現象といわれる都 市の温暖化が急速に進んでいる。過去 100 年において, 地球の平均気温が $0.7^{\circ} \mathrm{C}$ 上昇したのに対して，東京の 平均気温は $3.0^{\circ} \mathrm{C}$ 屯昇して扔り，諸外国の大都市に 比べてその温暖化は顕著である ${ }^{1)}$ 。特に夏季の大都市の 温暖化は生活環境を年々悪化させており，深刻な社会問 題になっている。このような背景のもと，近年，これを 抑制する技術として保水性舗装が注目を集めている。イ ンターロッキングブロックや平板といったコンクリート ブロックにおいても，保持した水分が蒸発する際に消費 する気化熱によって路面温度上昇を抑制する効果を有す る保水性コンクリートブロック舗装が開発され, 歩道・ 公園・広場などを中心にすでに 20 万 $\mathrm{m}^{2}$ 以上の施工実 績がある（2006 年 3 月現在）。こうした時勢のもと 2005 年 7 月には，社団法人 インターロッキングブロック舗 装技術協会（以下，インター協会とする）により保水性 コンクリートブロックの品質性能規格およびその試験方 法が制定された。

しかしながら, 保水性コンクリートブロック舗装は保 水性アスファルト舗装に比べると開発ならびに実施工の 歴史が浅く，路面温度上昇抑制効果に関する実証的な報 告は少ない。そこで, 著者らは太平洋セメント舗装ブロッ ク工業会（舗装用コンクリートブロック製造会社 44 社 および太平洋セメントグループで構成される工業会）の

*1 からさわ・あきひこ/太平洋セメント(株) 中央研究所 副主任研 究員 (正会員)

*2 ふじた・ひとし/太平洋セメント侏 中央研究所 研究員（正会 員)

＊3 えずみ・のりひろ/太平洋セメント舗装ブロック工業会 企画情 報委員会 委員長（策イズコン 常務取締役）

＊4たかもり・てつや/太平洋セメント舗装ブロック工業会 企画情

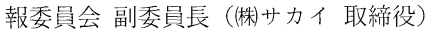

会員である製造会社において製造され，品質性能規格を 満足する 15 種類の保水性コンクリートブロックを施工. し, 実環境下における路面温度, 路面汃らの水分蒸発量, クッション砂の水分量等の経時変化を測定した。そして, これらの結果の解析から「保水性コンクリートブロック の品質性能」「コンクリートブロックの表面色」「クッショ ン砂抢よび目地砂の存在」「舗装への給水システム」が 路面温度に及ぼす影響を確認できたことから，これらを 取りまとめて報告する。

2. 保水性コンクリートブロックの品質性能規格

従来，保水性コンクリートブロックの品質性能規格は 製造会社間で統一されておらず，製造会社ごとに社内基 準が定められていた。そこで, インター協会は2004 年 9 月に官・学・民の委員から構成される保水性舗装用コ ンクリートブロック品質性能規格検討委員会〔委員長： 牧 恒雄・東京農業大学教授〕（以下，委員会とする） を設置して検討を行った。そして 2005 年 7 月, 保水性 コンクリートブロックの品質性能規格およびその試験方 法が制定された 携わったことから, 以下に品質性能規格の概要, 検討の 経緯，規格制定の根拠を紹介する。

保水性コンクリートブロックの品質性能規格の一部抜 粋を表-1 に示す。保水性コンクリートブロックは，前 述のように保持した水分が蒸発する際に消費する気化熱 による路面温度上昇抑制効果が必要之される。そのため, 品質性能規格としてブロック内部に水分を保持するため の保水性と，保持した水分をブロック上方に吸上げるた めの吸水性を定めた。保水性は, 保水性試験における保 水量で規定され，保水量は式（1）により算出している。 吸水性は, 吸水性試験における吸上げ高さで規定され, 吸上げ高さは式（2）により算出している。曲げ強度は, 
表-1＼cjkstart保水性コンクリートブロックの品質性能規格（一部抜粋）

\begin{tabular}{|c|c|c|c|}
\hline \multirow[b]{2}{*}{ 保水性 } & \multirow[b]{2}{*}{ 吸水性 } & \multicolumn{2}{|c|}{ 曲げ強度 $\left(\mathrm{N} / \mathrm{mm}^{2}\right)$} \\
\hline & & $\begin{array}{c}\text { 保水性インター } \\
\text { ロッキングブロック }\end{array}$ & 保水性平板 \\
\hline \multirow{3}{*}{$\begin{array}{c}\text { 保水量 } \\
0.15 \mathrm{~g} / \mathrm{cm}^{3}\end{array}$} & \multirow{3}{*}{$\begin{array}{c}30 \text { 分後の } \\
\text { 吸上げ高さ } \\
70 \% \text { 以上 }\end{array}$} & 3.0 以上 & 3.0 以上 \\
\hline & & - & 4.0 以上 \\
\hline & & 5.0 以上 & \\
\hline
\end{tabular}

保水量 $\left(\mathrm{g} / \mathrm{cm}^{3}\right)=\frac{\text { 湿潤質量 }(\mathrm{g}) \text { - 絶乾質量 }(\mathrm{g})}{\text { 保水性コンクリートブロックの体樍 }\left(\mathrm{cm}^{3}\right)}$

吸上げ高さ $(\%)=\frac{\text { 吸上げ質量 }(\mathrm{g}) \text { - 絶乾質量 }(\mathrm{g})}{\text { 湿潤質量 }(\mathrm{g}) \text { - 絶乾質量 }(\mathrm{g})} \times 100(2)$ ここに

湿潤質量：15 2 $5^{\circ} \mathrm{C}$ の清水中で 24 時間吸水させた後, 供試体を取り 出して, 図-1に示す密閉式のプラスチック容器に入れ, $15 \sim 30^{\circ} \mathrm{C}$ の室内で 30 分間水を切り, 絞った濡机ウエスで 目に見える水膜を妨くた後, 直ちに計測したときの質量

絶乾質量：温度 $105 \pm 5^{\circ} \mathrm{C}$ の乾燥器内において一定質量になるまで乾 燥した後，常温まで冷却したときの質量

吸上げ質量：絶乾状態の供試体を図-2に示す吸水性試験装置に設置 し，30 分経過後に供試体を取り出し，水が滴り落ちない 程度まで水を切り，絞った濡机ウェスで目に見える水膜を

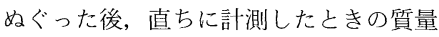

JIS A 5371 付属書の推奨仕様に規定される透水性イン ターロッキングブロック (3.0 N/ $\mathrm{mm}^{2}$ 以上), 普通イン ターロッキングブロック (5.0 N/ $\mathrm{mm}^{2}$ 以上), 透水平板 (3.0 N/mm $\mathrm{mm}^{2}$ 以上)，普通平板 $\left(4.0 \mathrm{~N} / \mathrm{mm}^{2}\right.$ 以上）と同 様の区分を設け，保水性コンクリートブロックの曲げ強 度に応じて，これら製品と同じ用途に適用できるように した。この他品質性能規格としては，すべり抵抗性と寸 法許容差が規定されているが，これらについては規格書 を参照されたい。

委員会での検討の経緯としては，「舗装の性能規定化」 の時勢を鑑みて，まずは保水性コンクリートブロック舗 装と密粒度アスファルト舗装の路面温度差を数值で規格 することを検討した。室内試験方法は, ランプの光を各々 の供試体表面に照射し, 両者の路面温度差を比較評価す る室内照射試験を検討したが，恒温恒湿恒風速などの条 件設定やランプの照射量設定が結果に及ぼす影響が大き く試験ごとの結果に整合性が得難いことから，保水性コ ンクリートブロック舗装と密粒度アスファルト舗装の路

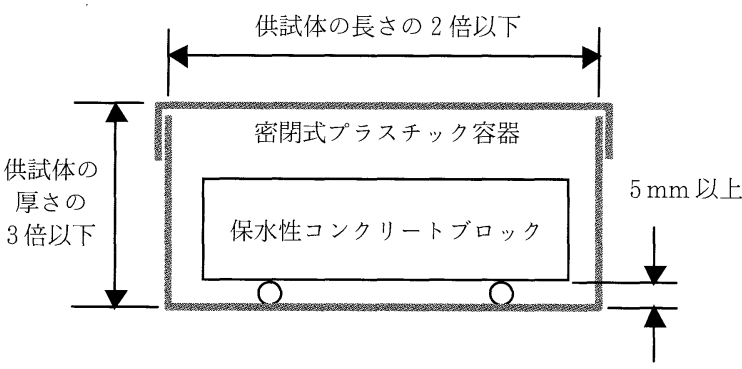

図-1＼cjkstart湿潤状態にする装置の概略図

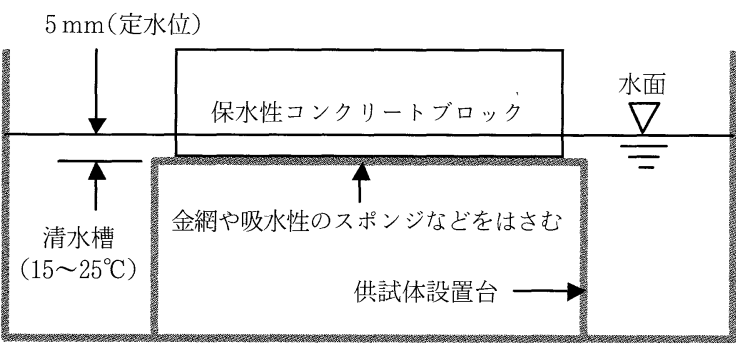

図-2＼cjkstart吸水性試験装置の概略図

面温度差を数值で規格するには至らなかった。

そこで, 委員会は保水性コンクリートブロックの品質 性能規格として，一般的なコンクリートブロック（普通 インターロッキングブロック，透水性インターロッキン グブロック，普通平板，透水平板）では制定されていな い保水性と吸水性を制定することとした。これにより， 一般的なコンクリートブロック舗装が密粒度アスファル 卜舗装に対して得られる路面温度上昇抑制効果と同等以 上の効果を得ることを考えた。保水性と吸水性の規格の 決定は, 一般的なコンクリートブロックとの差別化を図 るため, 委員会抢よびインター協会会員社において各種 室内評価試験を実施したほか，本論文に示す一連の研究 結果も鑑みて, 保水量 $0.15 \mathrm{~g} / \mathrm{cm}^{3}$ 以上, 吸上げ高さ $70 \%$ 以上とした。

なお，前述した室内照射試験は，各種の舗装材を同時 に試験し，路面温度差や水分蒸発量の差を相対評価する には有効な試験であると考え，技術資料として室内照射 試験方法を提示した ${ }^{3)}$ 。

Study of Effect of Water-retentive Pavement in Controlling the Temperature Rise of Road Surface By A. Karasawa, H. Fujita, N. Ezumi and T. Takamori

Concrete Journal, Vol.44, No.7, pp.9 16, Jul. 2006

Synopsis This paper reports the outline of the quality standard and test method of water-retentive concrete block pavement established by the Japan Interlocking Block Pavement Engineering Association (JIPEA) in July 2005. The authors confirmed the effectiveness of water-retentive concrete blocks in controlling the increase in road surface temperature in summer by field-testing fifteen types of standard-complying blocks constructed in an actual environment. Based on an analysis of the test results, the authors also report the effects on road surface temperature of the color of the concrete block surface, the quality of each type of block, the existence of cushion and joint sands, and the system of supplying water to the pavement.

Keywords : water-retentive pavement, concrete block, quality performance, road surface temperature 
3. 路面温度上昇抑制効果の屋外検証実験

\section{1 実 験 概 要}

屋外検証実験は,「保水性コンクリートブロックの品 質性能」「コンクリートブロックの表面色」「クッション 砂㧍よび目地砂の存在」「舗装への給水システム」が路 面温度に及ぼす影響を検証扔よび確認することを目的と して実施した。実験は, 千葉県佐倉市に写真-1 亿示寸実 験場を設け，2005 年 8 月 10 日から 9 月 9 日までの 1 か 月間継続的に各種測定を行った。以下にその概要を示す。

\subsection{1 舗装の種類}

実験対象とした舗装は, 保水性コンクリートブロック 舗装のほか, 各種コンクリートブロック舗装之密粒度了 スファルト舗装である。これら舗装の表層材の品質性能 および形状寸法を表一2 に示す。保水性コンクリートブ ロックは全 15 種類であり，これらはすべて前述の品質 性能規格を満足するものである。全 15 種類中, 透水性 を有さないものが 11 種類, 透水性を有するものが 4 種 類である。保水性コンクリートブロックは, すべて製品 会社に打ける実機に扔いて高振動加压即時脱型方式によ り製造された製品である。各々の保水性コンクリートブ ロックに抢いて，保水性㧍よび吸水性の付与に対する考 え方（例えば，高保水性を有する骨材の使用，空隙率・ 空隙径の調整等）は異なり，使われている材料，配合，

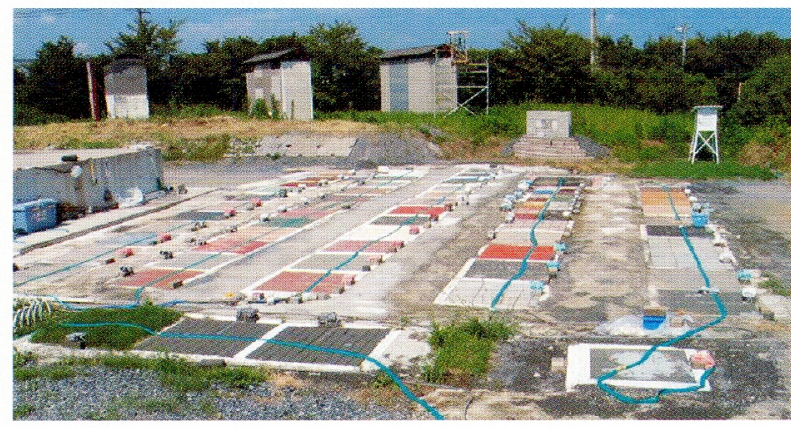

写真-1 屋外実験場
表面色は異なる。比較対象の舗装材は，普通インターロッ キングブロック，透水性インターロッキングブロック， 普通平板, 透水平板扮上び密粒度アスファルトとした。 インターロッキングブロックと平板は, JIS A 5371 付 属書の推奨仕様に適合するあのを使用した。普通インター ロッキングブロックは，配合は同一で表面色の異なる 12 種類を使用した。

\subsection{2 舖装構造}

舗装構造は，歩道舗装の標準的な構造とした た , 5)。コ ンクリートブロック舗装の構造断面は図-3に示すとお り，クッション層以下の構造はすべての舗装において同 じである。密粒度アスファルト舗装の構造断面を図-4 に示す。各舗装の面積は縦 $1 \mathrm{~m} \times$ 横 $1 \mathrm{~m}$ とし, 隣接す る舗装との境界には幅 $10 \mathrm{~cm}$ の断熱材（発泡スチロー ル）を設置した。コンクリートブロック舖装のクッショ ン砂には陸砂（静岡県産，粗粒率 2.61，吸水率 $1.73 \%$, 微粒分量 1.34\%）を使用した。目地幅は約 $3 \mathrm{~mm}$ とし, 目地砂には 5 号硅砂（山形県産, 粗粒率 1.94, 吸水率 0.25\%) を充てんした。敷設パターンは, 歩道舗装の一 般的な敷設パターンであるストレッチャーボンドパター

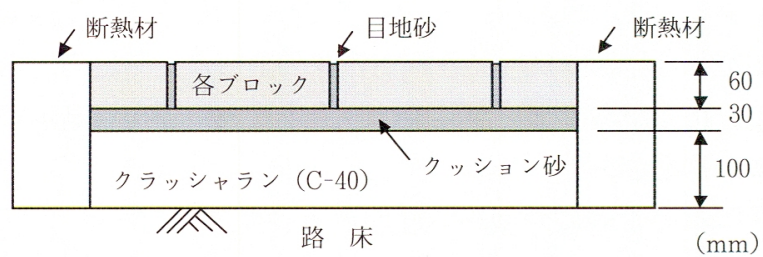

図-3 コンクリートブロック舗装の構造断面 (自然給水システム)

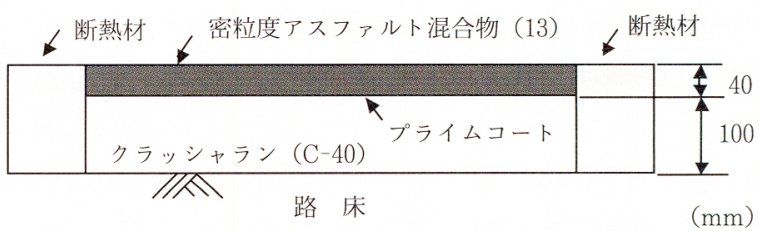

図-4＼cjkstart密粒度アスファルト舗装の構造断面

表-2 表層材の品質性能および形状寸法

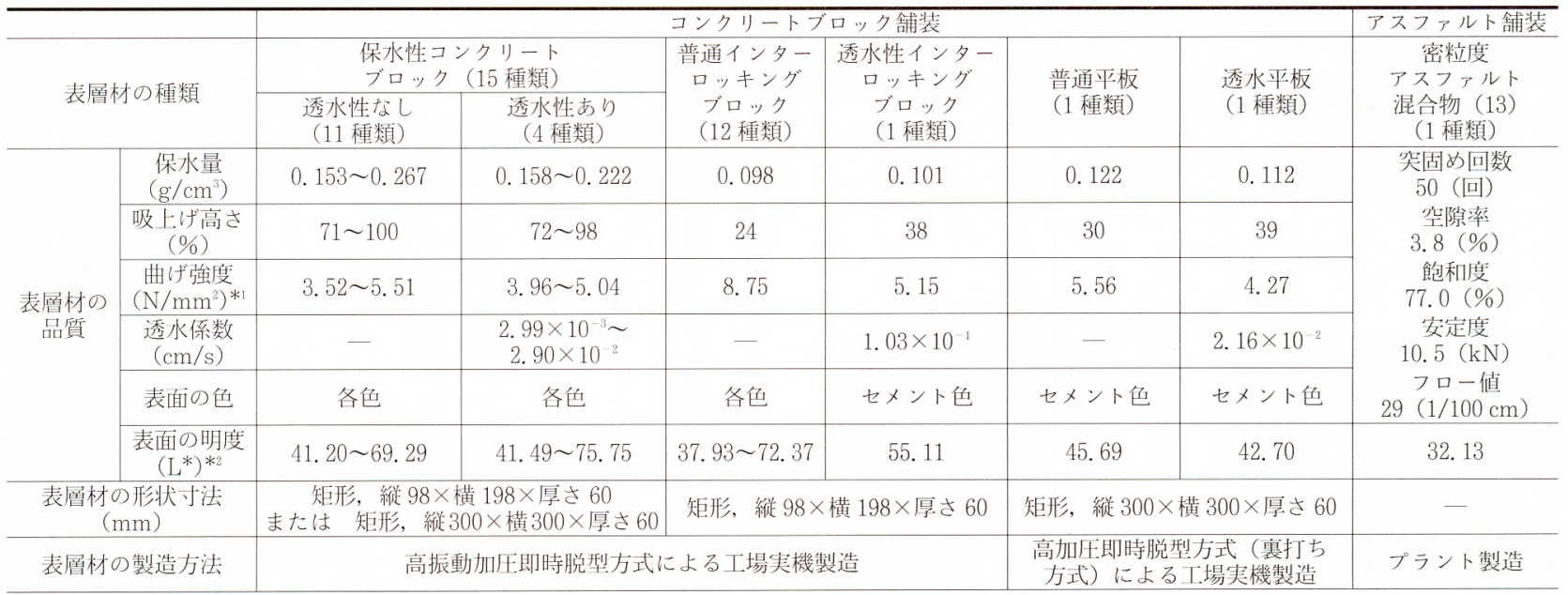

*1 屋外実験開始時の強度を示す。

*2 L*a*b*表色系の L*を示す。乾燥状態の $\mathrm{L}^{*}$ を示す。 
ンとした。

\section{1.3 給水システム}

保水性コンクリートブロック舗装に打ける給水システ ムは，図-3に示したと扮り給水設備を設けず自然降雨 により給水在行うシステム（以下，自然給水システム之 する）のほか，図-5に示すように給水設備を設けて， 舗装内部に定期的に給水を行うシステム（以下，強制給 水システムとする）についても自然給水システムと同様 の保水性コンクリートブロックを用いて実験を行った。 強制給水システムは, 写真-2 に示すように，コンクリー 卜路盤の上に遮水用の鋼板を立上げ，この内部にドリッ プ式の給水管を配置し，クッション砂で埋め戻した後に ブロックを敷設する構造とした。給水は自動夕イマーに より管理し，3日に1回，午前７時加ら給水を開始し， 遮水用鋼板上部加らのオーバーフローをモイスチャ一セ ンサーで感知した時点で給水を停止する管理を行った。

\section{1.4 測定項目}

本実験では，「路面温度」「路面からの水分蒸発量」 「クッション砂の水分量」の経時的変化を測定した。路 面温度は, 路面下 $5 \mathrm{~mm}$ の位置に熱電対（銅-コンス夕 ンタン）を埋め込み，データロガーにより 1 時間間隔で 測定した。さらに, 赤外線熱画像装置により測定を行っ た。路面加らの水分蒸発量は, 密閉式水分蒸発量測定器 により測定を行った。クッション砂の水分量は, ブロッ クの中の 1 個に表面から底面に貫通する を開けて扮き，この穴を通してクッション砂に土壌水分 量測定器を挿入することによって行った。測定を行わな い時にはゴム栓によって穴考塞いで打いた。なお，これ らの測定は縦 $1 \mathrm{~m} \times$ 横 $1 \mathrm{~m}$ の舗装の中央付近で行った。

\section{2 実験結果および考察}

2005 年 8 月 13 日午前 2 時から午前 8 時にかけて総雨 量 $14 \mathrm{~mm}$ の降雨があり当日は量り, 翌日 8 月 14 日は 晴天で 14 時に 8 月の当地の最高気温 $33.8^{\circ} \mathrm{C}$ を記録し,

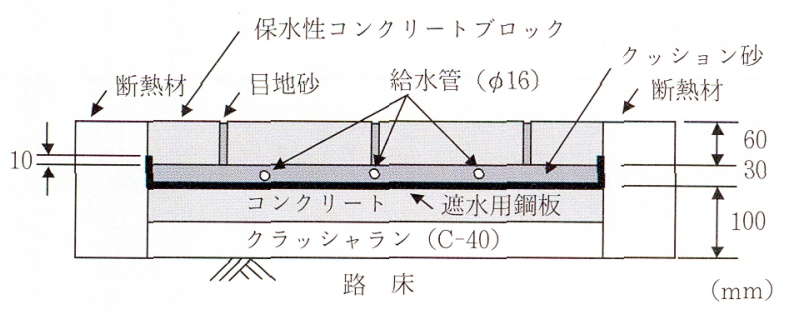

図-5 強制給水システム
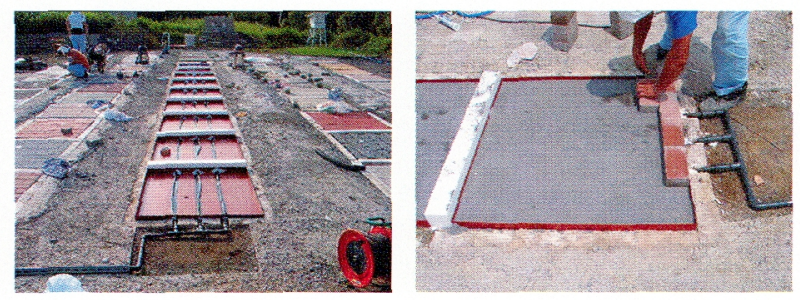

写真-2 強制給水システムの施工
その後 8 月 21 日まで晴天が 8 日間続いた気象条件下で の実験結果抢よび考察を以下に示す。

\subsection{1 コンクリートブロックの表面色が路面温度に}

\section{及ぼす影響}

降雨翌日（8月14日14 時）の普通インターロッキン グブロック舗装におけるブロック表面明度と路面温度の 関係を図-6に示す。ここに既往の研究から，地表面の 熱収支に沶いて式（3）が成立つことが分かっている ${ }^{6)}$

$$
R_{n}=S(1-\alpha)+L \downarrow-L \uparrow=H+\ell E+G
$$
ここに,

$$
\begin{aligned}
& R_{n}: \text { 地表面が受け取る正味の放射熱量 } \\
& S: \text { 太陽放射（直達成分十散乱成分） } \\
& \alpha: \text { 太陽放射の反射率（アルベド） } \\
& L \downarrow: \text { 大気放射 } \\
& L \uparrow: \text { 地球放射 } \\
& H: \text { : 対流による顕熱輸送 } \\
& \ell E: \text { 気化による潜熱輸送 } \\
& G: \text { 伝導による地中への熱輸送 }
\end{aligned}
$$

図-6においてブロック表面明度が高い普通インター ロッキングブロック舗装ほど路面温度が低い相関関係が 認められ，白色のブロックは黒色のブロックに比べて路 面温度が $5.1^{\circ} \mathrm{C}$ 低い結果であった。これは，ブロック 表面明度が高いほど式（3）に示す $\alpha$ （太陽放射の反射 率）が大きいためであると考えられる。

本実験に使用した各種コンクリートブロック舗装のブ ロックの表面色はすべて異なるため，表面色の影響を無 視して路面温度を比較することはできない。このため, 密粒度アスファルト舗装以外のコンクリートブロック舗 装ではブロック表面明度と気温を説明变数とした重回帰 式を用いてブロック表面明度を 64 に合わせて路面温度 の補正を行った。以下に示すコンクリートブロック舗装 の路面温度は, 明度 64 補正後の路面温度である。なお， 表面明度 64 の設定は，保水性セメントミルクを充てん する方式の保水性アスファルト舗装の表面明度が 64 程

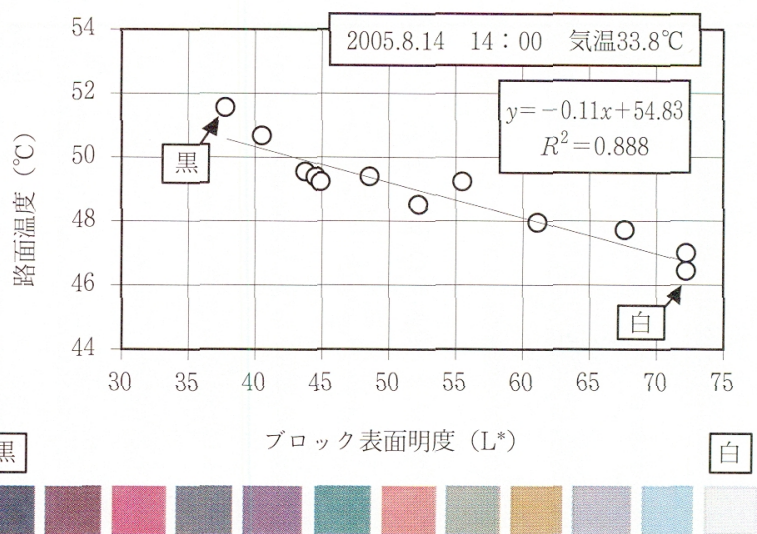

四中のマーカーに対厽する普通インターロッキング ブロックの表面写真を示す

図-6 普通インターロッキングブロック舗装における ブロック表面明度と路面温度の関係 


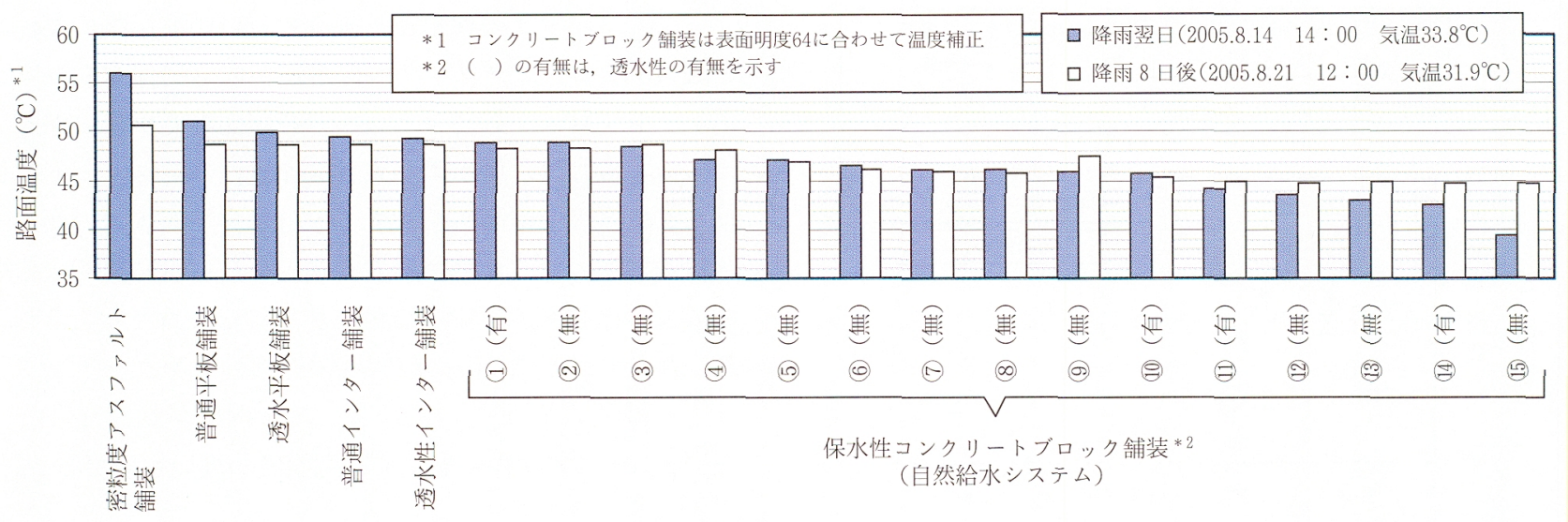

図-7＼cjkstart各舗装の路面温度の比較

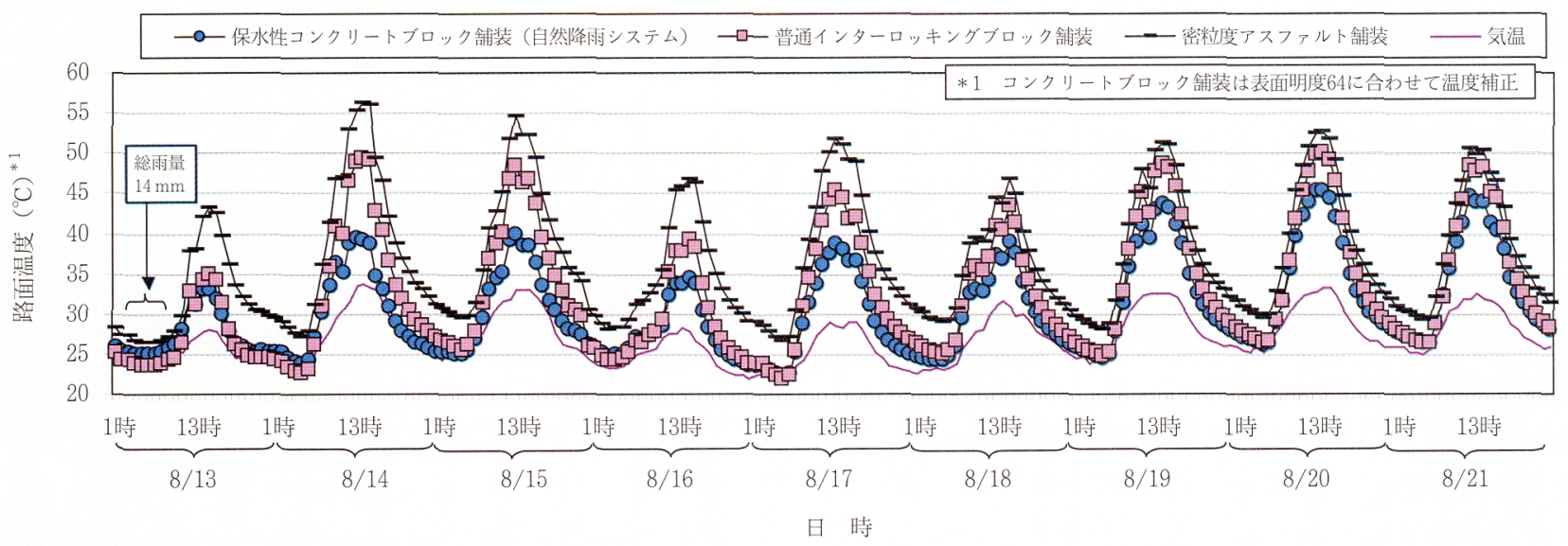

図-8 各舗装の路面温度の経時変化

度であるため，これに合わせての設定である。

\section{2 .2 保水性コンクリートブロック舗装（自然給水} システム) の路面温度上昇抑制効果

降雨翌日（8月 14 日 $14 ： 00$ 気温 $33.8^{\circ} \mathrm{C}$ ) と降雨 8

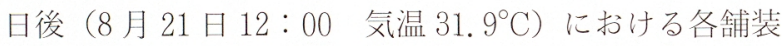
の路面温度の比較走図-7に, 降雨当日加ら降雨 8 日後 の各舗装の路面温度の経時変化を図-8に示す。図-8に 示す保水性コンクリートブロック舗装は, 図-7 (15)の舗 装を示す。図-7から, 降雨翌日の密粒度アスファルト 舗装の路面温度が $56.1^{\circ} \mathrm{C}$ に昇したのに対して 15 種 類の保水性コンクリートブロック舗装の路面温度は 39. 5 48. $9^{\circ} \mathrm{C}$ であった。すなわち，保水性コンクリ一 トブロック舗装は, 降雨翌日の気温 $33.8^{\circ} \mathrm{C}$ の気象条件 下に扔いて，密粒度アスファルト舗装に比べて 7.2〜 $16.6^{\circ} \mathrm{C}$ の路面温度上昇抑制効果が認められた。また, 他のコンクリートブロック舗装（普通インターロッキン グブロック舖装，透水性インターロッキングブロック舗 装，普通平板舗装，透水平板舗装）と比べても路面温度 上昇抑制効果が認められた。威-8 から，保水性コンク リートブロック舗装は夜間に扮いても密粒度アスファル 卜舖装に比べて路面温度上昇抑制効果が認められた。 図-9には降雨翌日（8月 14日 11：00 気温 $30.6^{\circ} \mathrm{C}$ ) の赤外線熱画像を示す。これからも保水性コンクリート ブロック舖装は，他舗装に比べて路面温度上昇抑制効果
が確認できる。図-10は，各舗装上にスプリンクラーに て散水（8月 29日 8:00 9:00 $30 \mathrm{~mm} / \mathrm{h}$ 散水）し た翌日（8月 30 日 $12: 00$ 気温 $30.3^{\circ} \mathrm{C}$, 相対湿度 30.3 ${ }^{\circ} \mathrm{C}$, 風速 $3 \mathrm{~m} / \mathrm{s}$ ) に打け万各舗装の路面汃らの水分蒸発 量と路面温度の関係を示す。15 種類の保水性コンクリー トブロック舖装の水分蒸発量は, お扎む敉他のコンクリー トブロック舗装よりも大きく, 水分蒸発量が大きい舗装 ほど路面温度が低い傾向にある。既往の多くの研究加ら, 保水性舗装の路面温度上昇抑制効果の要因として, 前記 式（3）における $\ell E （$ 気化による潜熱輸送）が大きな

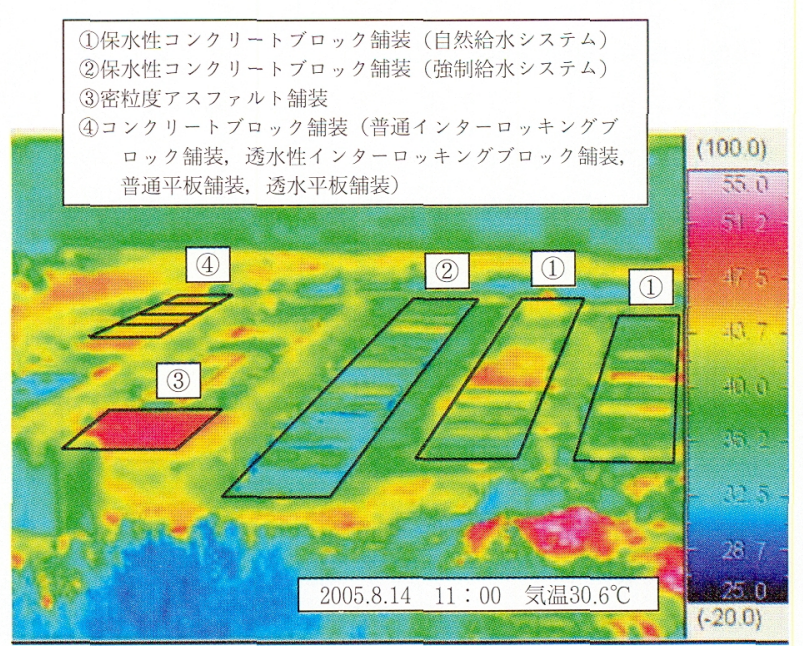

図-9＼cjkstart降雨翌日の赤外線熱画像 


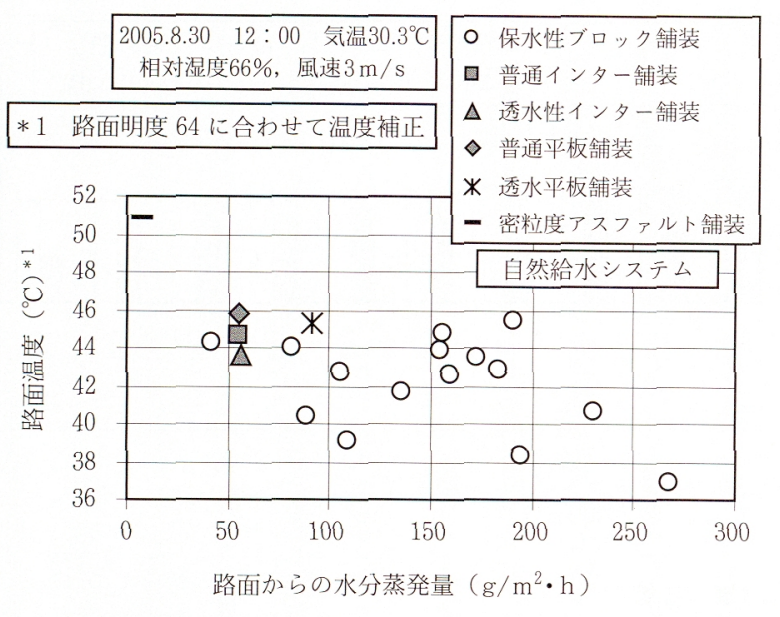

図-10 散水翌日の路面からの水分蒸発量と路面温度の関係

割合を占好ことが分かっているが，本実験においても このことが確認できた。なお，図-10においてそ机ほど 高い相関性が得られていないのは, 15 種類の保水性コ ンクリートブロックに沶いて各々熱伝導率や熱容量が異 なり, 式（3）に示した $G （$ 伝導による地中への熱輸送 量）が異なることが影響していると考えられる。

次に, 図一7から保水性コンクリートブロック舗装は, 降雨 8 日後において屯密粒度アスファルト舗装に比べて

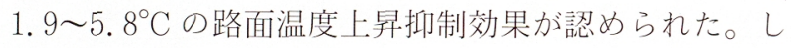
かし, 降雨翌日に比べるとの温度差は減少して扔り, これは図-8からも分かる。これは, 時間の経過に伴い 舗装体内の水分量が減少し, 路面からの水分蒸発量が減 少しているためであると考えら机る。図-7 加ら保水性 コンクリートブロック舗装における降雨翌日上降雨 8 日 後の路面温度の関係を見ると, 降雨翌日の路面温度が低 い舖装は, 降雨 8 日後の路面温度む低い傾向にある。言 い換えれば，降雨翌日の路面温度上昇抑制効果が高い保 水性コンクリートブロック舗装は, その効果の持続性も 高い傾向が認められた。

\subsection{3 保水性コンクリートブロックの品質性能が路 面温度に及ぼす影響}

（1）ブロックの保水量㧍よび吸上げ高さの影響

ブロックの吸上げ高さ上降雨翌日（8月14日 14 時） の路面温度の関係を図-11 に示す。ブロックの吸上げ高 さが大きい保水性コンクリートブロック舖装ほどおおお 权路面温度が低い傾向にある。これは, ブロックの吸上 げ高さが大きい保水性コンクリートブロック舖装は路面 加の水分蒸発量が大きく, 気化熱の消費による路面温 度上昇抑制効果が大きいためであると考えられる。図-7 (15)の保水性コンクリートブロックと普通インターロッキ ングブロックの水銀圧入式ポロシメー夕による細孔径分 布測定結果を図-12 亿示す。この保水性コンクリートブ ロックは，普通インターロッキングブロックに比べると 0. 003 400 $\mu \mathrm{m}$ に分布する直径の細孔が数多く存在して 抢り，これが毛細管現象による水分蒸発量の大きさに寄 与していると考えられる。
次に, ブロックの保水量上降雨翌日の路面温度の関係 を図-13 に示す。ブロックの保水量が大きい保水性コン クリートブロック舖装ほど招打む拜路面温度が低い傾向 にある。これは，保水量が大きな保水性コンクリートブ ロックは，吸上げ高さが大きく水分蒸発量が大きい傾向 があるに加えて，比熱加増大し式（3）に示した $G$ (伝 導に上る地中への熱輸送）が小さくなるため上考えられ る。ただし, 図-13 中の破線外の保水性コンクリートブ ロック舗装のように，ブロックの保水量が $0.20 \mathrm{~g} / \mathrm{cm}^{3}$ 以上之大きいにもかかわら或路面温度が高いものがある。

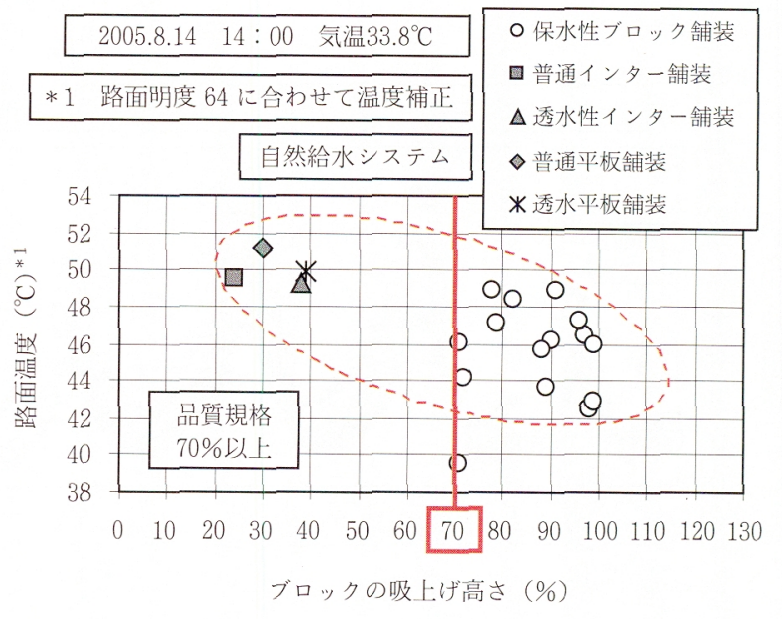

図-11 ブロックの吸上げ高さと降雨翌日の路面温度の関係

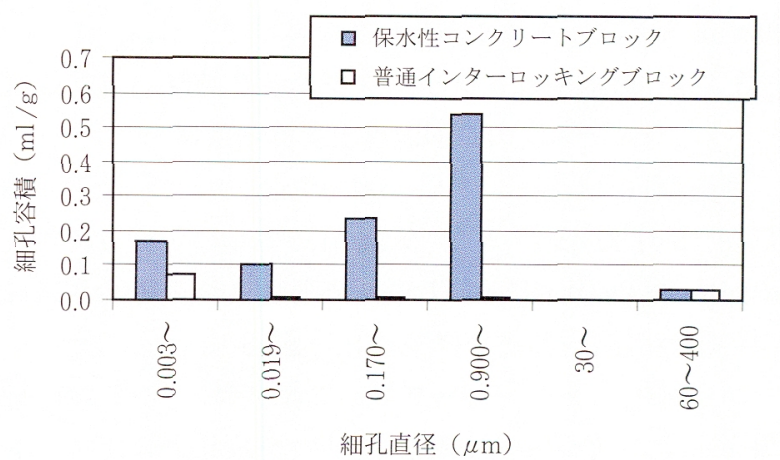

図-12 ブロックの細孔径分布測定結果

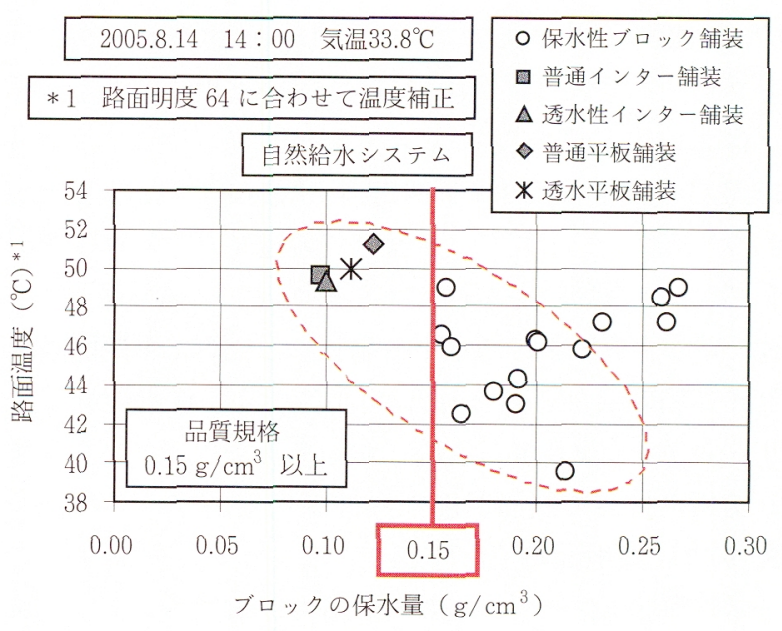

図-13 ブロックの保水量と降雨翌日の路面温度の関係 
これは，保水性コンクリートブロックに混入されている 保水材の熱的性質が関係している可能性があり，今後分 析を進める予定である。

\section{（2）ブロックの透水性の影響}

図一7に示したように，保水性コンクリートブロック の透水性の有無と路面温度に相関関係は認められなかっ た。透水性を有する保水性コンクリートブロックでも同 様に，透水性の大小（透水係数の大小）之路面温度に相 関関係は認められなかった。これは，透水性に寄与する ブロックの空隙径と毛細管現象による水分蒸発に寄与す る空隙径が異なるためと考えられる。

\subsection{4 クッション砂および目地砂が路面温度に及ぼ す影響}

(1) クッション砂の影響

各舗装上にスプリンクラーにて $30 \mathrm{~mm} / \mathrm{h}$ の散水（8 月29日 8：00〜9：00）をした後の晴天下のクッショ ン砂の水分量経時变化を図-14 に示す。図中の保水性コ ンクリートブロック舗装は図-7 (15)の舗装を用いている。 保水性コンクリートブロック舗装と普通インターロッキ ングブロック舗装は，ともに時間の経過に伴ってクッショ ン砂の水分量が低下しているが，その低下の割合は保水 性コンクリートブロック舖装の方が大きい。そして, 路 面からの水分蒸発量が大きい保水性コンクリートブロッ

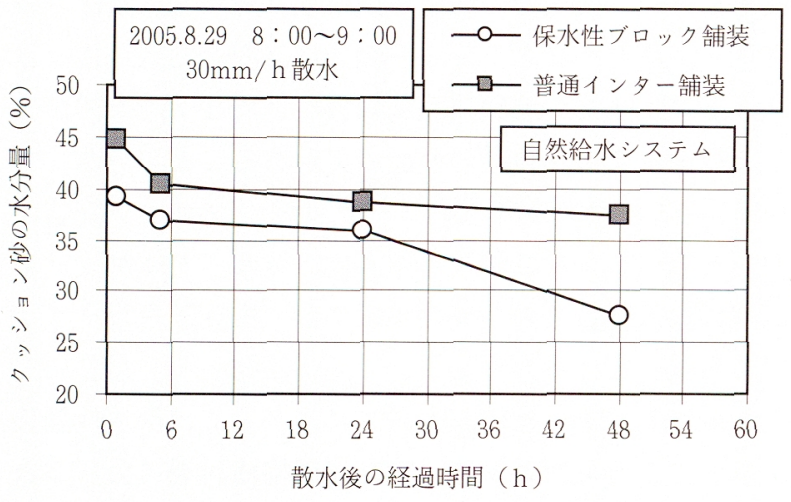

図-14 散水後のクッション砂水分量の経時変化

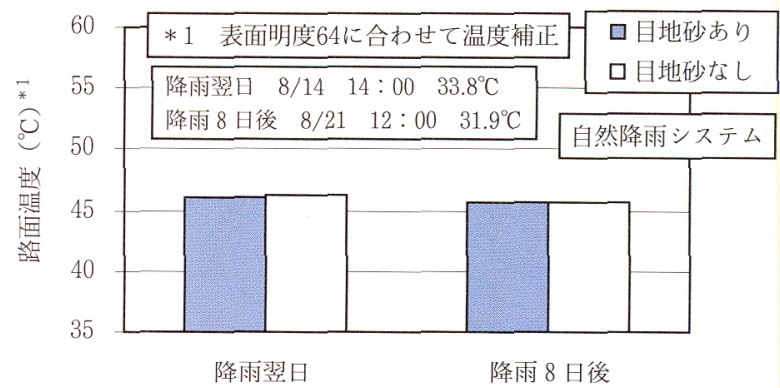

図-15＼cjkstart目地砂の有無による路面温度の比較

ク舗装ほどクッション砂の水分量の低下の割合が大きい 傾向にあることを確認している。

これらのことから, クッション砂の水分量は保水性コ ンクリートブロック舗装の路面温度上昇抑制効果の持続 性に寄与している可能性があると考えられる。

\section{（2）日地砂の影響}

図-7８０保水性コンクリートブロック舗装に㧍いて, 目地砂（5号硅砂）を充てんした舗装と充てんしない舗 装を施工し，路面温度を比較した結果を図-15に示す。 降雨翌日（8月14日 14：00 気温 $33.8^{\circ} \mathrm{C}$ ） 乙降雨 8 日 後（8月 21 日 $12 ： 00$ 気温 $31.9^{\circ} \mathrm{C}$ ） と屯に目地砂のあ りとなしで路面温度の違いはない。これは, 路面に扔け 万目地 (3 mm 幅) の面積が保水性コンクリートブロッ ク（縦 $98 \mathrm{~mm} \times$ 横 $198 \mathrm{~mm}$ の矩形）の面積に対して, その約 4\%であり, 目地砂の保水性や吸水性が路面温度 に与える影響が小さいためであると考えられる。

ただし，目地砂にはブロック相互の噛み合わせ効果を 発揮させる役割や，一定の目地幅を確保してブロックの 破損を防止する役割があるため，他のコンクリートブロッ ク同様, 保水性コンクリートブロック舗装にとって目地 砂は重要な舗装構成材料である。

\subsection{5 給水システムが路面温度に及ぼす影響}

8 月 18 日から 8 月 20 日の晴天下における自然給水シ ステムと強制給水システムの路面温度の比較を図-16に 示す。図中の保水性コンクリートブロック舗装は, 図-7

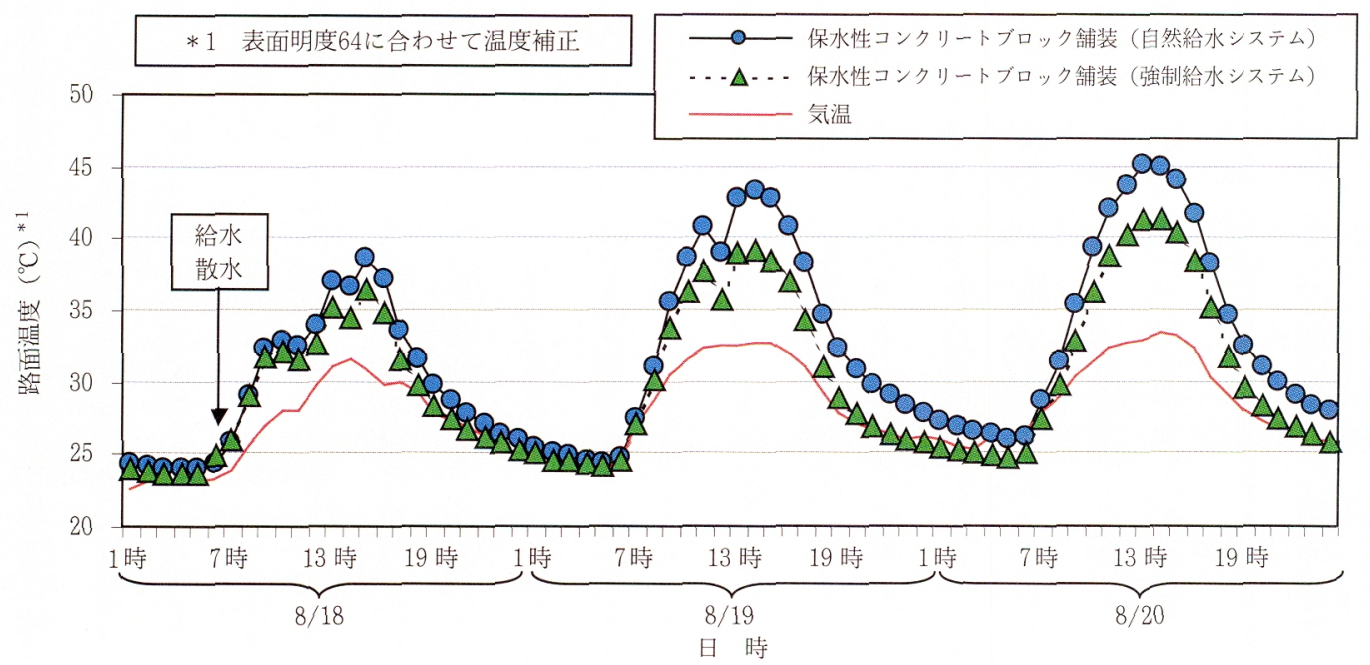

図-16＼cjkstart給水システムの違いによる路面温度の比較 
(15)の舗装を用いている。強制給水システムでは，8月 18 日午前 7 時から給水を開始し，遮水用鋼板上部からのオー バーフローをモイスチャーセンサーで感知した時点で給 水を停止している。自然給水システムでは，8月18日 午前 7 時から 8 時までスプリンクラーで舗装上に 30 $\mathrm{mm} / \mathrm{h}$ の散水を行った。強制給水システムの路面温度 は, 自然給水システムに比べて 8 月 18 日は約 $1^{\circ} \mathrm{C}$ の低 下であるが，8月 19 日と 20 日では約 $4^{\circ} \mathrm{C}$ 低下しており， 時間経過に伴ってその差が大きくなっている。これは, 前述のように, クッション砂の水分量が保水性コンクリー トブロック舗装の路面温度上昇抑制効果の持続性に寄与 している可能性があり，強制給水システムは，自然給水 システムに比べてクッション砂の水分量が大きい状態を 長時間維持できることが影響していると考えられる。

これらのことから，保水性コンクリートブロック舗装 に抢ける強制給水システムは, 自然給水システムに比べ て優れた路面温度上昇抑制効果を長時間維持できる可能 性があることが分かった。

\section{4. まとめ}

路面温度上昇抑制効果の屋外検証実験から得られた知 見を以下にまとめる。

1）コンクリートブロック舖装では，ブロックの表面 明度 $\left(\mathrm{L}^{*}\right)$ が高いほど路面温度が低くなることが 分かった。

2）保水性コンクリートブロックの品質性能規格を満 足する 15 種類のブロックを使用した保水性コンク リートブロック舗装は, 降雨翌日の気温 $33.8^{\circ} \mathrm{C} の$ 気象条件下において, 密粒度アスファルト舗装に比 ベて $7.2 \sim 16.6^{\circ} \mathrm{C}$ の路面温度上昇抑制効果が認め られた（ブロックの表面明度を 64 に補正した場合）。

3）路面からの水分蒸発量が大きい保水性コンクリー トブロック舗装ほど路面温度が低い傾向が認められた。

4）降雨翌日の路面温度上昇抑制効果が高い保水性コ ンクリートブロック舗装は，その効果の持続性む高 い傾向が認められた。

5）ブロックの吸上げ高さが大きい保水性コンクリー トブロック舗装ほど路面温度が低い傾向が認められた。

6）ブロックの保水量が大きい保水性コンクリートブ ロック舗装ほど路面温度が低い傾向が認められた。 ただし，一部のブロックでは保水量が大きいにもか かわらず路面温度が高い結果であり，これはブロッ クに混入されている保水材の熱的性質が関係してい る可能性が考えられる。

7）保水性コンクリートブロックの透水性の有無と路 面温度に相関関係は認められなかった。透水性を有 する保水性コンクリートブロックでも同様に，透水
性の大小（透水係数の大小）上路面温度に相関関係 は認められなかった。

8）クッション砂の水分量は保水性コンクリートブロッ ク舗装の路面温度上昇抑制効果の持続性に寄与して いる可能性があることが分かった。

9）目地幅 $3 \mathrm{~mm}$ の条件において，目地砂の有無に よる保水性コンクリートブロック舗装の路面温度の 違いは認められず，目地砂の存在が路面温度に与え る影響は小さいと考えられる。

10）保水性コンクリートブロック舗装に打ける強制給 水システムは, 自然給水システムに比べて優れた路 面温度上昇抑制効果を長時間維持できる可能性があ ることが分かった。

\section{5.おわりに}

一連の研究汃ら，路面温度上昇抑制効果に優れた保水 性コンクリートブロック舗装を構築するための必要条件 の一部を確認することができたと考える。本研究成果が 現在盛んに進められている保水性コンクリートブロック 舗装の開発の一助となり, 都市のヒートアイランド現象 の抑制に貢献できれば幸いである。なお，保水性コンク リートブロック舗装はその多彩な景観性から, 歩道・公 園・広場といった人の活動の場での施工実績が多く, 今 後むこういった場での適用が期待されている。既往の研 究から, 保水性アスファルト舗装は路面温度低減による ヒートアイランド現象の抑制効果だけでなく，人体が受 ける放射による熱負荷の軽減効果があることが分かって いる7。。このた，保水性コンクリートブロック舗装に おいても, これらの研究を参考に, 今後, 人体が受ける 放射による熱負荷の軽減の効果について評価を行う予定 である。

最後になりましたが，本研究にあたっては保水性舗装 用コンクリートブロック品質性能規格検討委員会（委員 長：牧 恒雄・東京農業大学教授）の各委員抢よび関係 各位より，貴重なご意見，ご指導をいただきましたこと を心より御礼申し上げます。

\section{参 考 文 献}

1）気象庁：20世紀の日本の気候，2002.5

2）（社）インターロッキングブロック舗装技術協会：保水性舗装用 コンクリートブロック品質性能規格, 2005.7

3）（社）インターロッキングブロック舗装技術協会：保水性舗装用 コンクリートブロックの室内照射試験および凍結融解試験 技術 資料，2005.7

4）（社）日本道路協会：アスファルト舗装要綱, 1997.7

5）（社）インターロッキングブロック舗装技術協会：インターロッ キングブロック舖装設計施工要領, 2000.7

6）有田正光・岡本博司・小池俊雄 - 中井正則・福島武彦・藤野 毅 : 大気圏の環境，東京電機大学出版局，2000.1

7）藤野 毅・長島博雄・菅沼忠嗣・过井 豪：保水性舗装のテーマ パークへの適用と熱負荷軽減効果, 舗装, Vol. 40, No. 3, 2005. 3 